\title{
WEB E-COMMERCE PADA TOKO BUKU UMAT UNTUK MENINGKATKAN EVEKTIVITAS PEMASARAN
}

\author{
Herdiesel Santoso ${ }^{1}$, Minarwati², Kholidun ${ }^{3}$ \\ 1,2, STMIK El Rahma, Yogyakarta, Indonesia \\ E-mail: 1herdiesel.santoso@stmikelrahma.ac.id,2iin_spb@yahoo.com,3kholidldk@gmail.com
}

\begin{abstract}
The aim of this study is to build an e-commerce website in umat bookstore to expand marketing and manage product management. The stages of system development follow the SDLC model, namely analysis, design, implementation and evaluation. Initial system analysis uses the PIECES framework. Documentation results from the system weakness analysis stage are used for recommendations on system requirements and what functionality a new system will perform. After the analysis phase is complete, the proposed system requirements are translated into system design. The design phase uses the United Modeling Language (UML) which consists of use case diagrams, activity diagrams, sequence diagrams and class diagrams. The data modeling phase consists of two stages, namely, designing a database conceptual model and physical database design. Interface design includes backend design and frontend. The next step is the implementation of the program design phase translated into codes using a programming language. At this stage system testing is also carried out. Evaluation results show that the functions of e-commerce webs can run well and help umat bookstore provide fast, accurate and relevant information so as to increase the effectiveness of product promotions.
\end{abstract}

Keywords: Information system, e-commerce, SDLC, PIECES, UML

\begin{abstract}
Abstrak.Tujuan penelitian ini adalah membangun web e-commerce di toko buku umat untuk memperluas pemasaran dan melakukan manajemen produk. Tahapan pengembangan sistem mengikuti model SDLC, yaitu analisis, desain, impelementasi dan evaluasi. Analisis sistem awal menggunakan kerangka PIECE. Hasil dokumentai dari tahap analisis kelemahan sistem digunakan untuk rekomendasi kebutuhan sistem dan fungsionalitas apa saja yang akan dilakukan sistem baru. Setelah tahap analisis selesai, usulan kebutuhan sistem diterjemahkan menjadi desain sistem. Tahapan desain menggunakan United Modelling Language (UML) yang terdiri dari use case diagram, activity diagram, sequence diagram dan class diagram. Tahap pemodelan data terdiri dari dua tahap yaitu, perancangan model konseptual database dan perancangan fisik database. Desain antarmuka meliputi desain halaman administrator dan desain halaman depan. Tahap selanjutnya adalah implementasi dari fase desain program diterjemahkan ke dalam kode-kode dengan menggunakan bahasa pemrograman. Pada tahapan ini juga dilakukan pengujian sistem. Hasil evaluasi menunjukan fungsi-fungsi web e-commerce dapat berjalan dengan baik dan membantu toko buku umat menyediakan informasi yang cepat, akurat dan relevan sehingga meningkatkan efektivitas promosi produk.
\end{abstract}

Kata Kunci: Sistem informasi, e-commerce, SDLC, PIECES, UML 


\section{Pendahuluan}

Tantangan yang dihadapi oleh organisasi di era milenial ini adalah memaksimalkan segala potensi yang dimiliki untuk menyediakan informasi yang cepat, akurat dan relevan. Penelitian Alghamdi \& Bach (2014), mengungkapkan bahwa, penggunaan teknologi terutama internet sebagai saluran untuk perdagangan dan informasi telah memberikan kesempatan bagi bisnis untuk meningkatkan evektivitas pemasaran. Teknologi internet layak dipertimbangkan sebuah bisnis agar dapat membangun hubungan dengan konsumen dan lebih berkompeten untuk mengatasi persaingan-persaingan yang timbul antara perusahaan sejenis. Konsumen merupakan salah satu aset yang berperan penting dalam pencapaian tujuan perusahaan, menjaga hubungan baik dengan konsumen dengan memberi pelayanan prima kepada konsumen merupakan hal mutlak yang harus dilakukan.

E-commerce

(elektronik commerce) merupakan kegiatan menjual atau membeli barang serta jasa secara electronik dengan menggunakan teknologi jaringan internet (Khan, 2016). Teknologi e-commerce dapat dimanfaatkan oleh konsumen melalui model business to consumer maupun oleh pelaku bisnis melalui model business to business (Shahriari, Shahriari, \& Gheiji, 2015). E-Commerce memiliki keuntungan, diantaranya dapat diakses dari mana saja dan kapan saja, memungkinkan akses informasi untuk promosi serta pemasaran dapat dilakukan seluas - luasnya tanpa tanpa harus terhalang oleh waktu dan tempat sehingga dapat peningkatan efektifitas pemasaran (Fithri, Utomo, \& Nugraha,
2017; Susandi \& Sukisno, 2017). Hasil penelitian dari Mumtahana, Nita, \& Tito (2017), menunjukkan bahwa dengan memanfaatkan teknologi e-commerce memenuhi strategi pemasaran produk yang dapat berdampak pada peningkatan pendapatan.

Toko buku Umat bergerak dibidang penjuaan buku dengan cara bekerjasama dengan distributor buku. Sistem pengolah data dan pemasaran pada toko buku Umat, masih dilakukan secara manual. Sistem manual ini berpotensi menimbulkan kesalahan dalam pemrosesan data. Misalnya, sulitnya melakukan pengecekan data produk yang ada dengan produk yang telah terjual karena media penyimpanannya melalui kertas. Setiap data yang pemesanan produk via telepon, WA dan sms, harus dicatat secara manual sehingga memakan waktu dan memungkinkan kesalahan dalam proses pencatatan transaksi. Selama ini produkproduknya yang dijual di internet dipasarkan dengan memanfaatkan sosial media seperti facebook dan instagram. Metode penjualan online di sosial media juga masih memiliki keterbatasan, algoritma sosial media selalu berubah, hal ini menjadi kendala bagi penjual online dalam hal promosi produk. Keterbatasan yang lain terdapat pada kontennya yang terbatas hanya beberapa karakter, sehingga kurang maksimal dalam menampilkan detail katalog produk. Ketika akan menampilkan harga, juga terbatas hanya caption atau badan postingan. Permasalahan lainnya ketika mencari buku yang ingin dibeli, pada sosial media tidak ada pencarian spesifik produk.

Untuk memperluas pemasaran dan melakukan manajemen produk dari toko buku Umat maka diperlukan web $e$ commerce. Aplikasi ini dirancang 
memiliki pembagian hak akses pengguna yaitu: administrator, pemilik toko (owner), dan konsumen. Konsumen dapat melihat informasi produk secara detail, termasuk ongkos kirim dan posisi barang (tracking) setelah dikirim hingga sampai ke tangan konsumen. Dengan adanya teknologi web e-commerce diharapkan toko buku Umat dapat menyediakan informasi yang cepat, akurat dan relevan sehingga meningkatkan efektivitas promosi produk.

\section{Metode Penelitian}

Tahapan pengembangan sistem mengikuti model System Development Life Cycle (SDLC) yang merupakan metodologi umum dalam pengembangan sistem yang menandai kemajuan usaha analisis dan desain (Balaji \& Murugaiyan, 2012). Langkah-langkah yang dilakukan dalam pengembangan sistem menggunakan metode SDLC dapat dilihat pada diagram alir pada gambar 1.

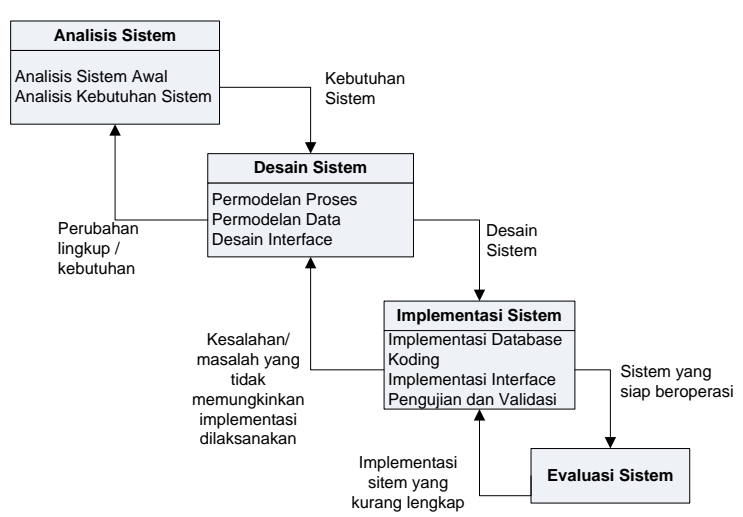

Gambar 1. Tahapan Pengembangan Sistem Dengan SDLC

\section{Analisis Sistem}

Tahapan analisis adalah tahapan di mana sistem yang sedang berjalan dipelajari dan sistem pengganti diusulkan. Tujuan utama dari fase analisis adalah untuk memahami dan mendokumentasikan kebutuhan bisnis dan persyaratan proses dari sistem baru.

Analisis sistem awal terfokus pada aliran data dan poses bisnis yang sedang berjalan di toko buku Umat. Untuk mempermudah cara melakukan analisa sistem awal, kami menggunakan kerangka PIECES yang menguraikan analisis ke dalam 6 fokus analisis kelemahan yaitu kinerja, informasi, ekonomi, keamanan, efisiensi, dan pelayanan (Saptari \& Saptari, 2017).

Hasil dokumentai dari tahap analisis kelemahan sistem digunakan untuk rekomendasi fungsionalitas apa saja yang akan dilakukan sistem baru. Untuk mempermudah sistem analis menentukan keseluruhan requirement secara lengkap, maka analis membagi kebutuhan sistem ke dalam 2 jenis. Jenis pertama adalah Kebutuhan Fungsional (Functional requirement). Jenis kedua adalah Kebutuhan Non Fungsional (Nonfunctional Requirements).

\section{Desain Sistem}

Pada tahap ini akan dibuat desain model proses, model data, dan desain antarmuka. Desain model proses digambarkan dengan United Modelling Language (UML). UML adalah 'bahasa' pemodelan untuk sistem atau perangkat lunak yang berparadigma 'berorientasi objek'. Terdapat diagram untuk memvisualisasikan, menspesifkasikan, membangun, dan mendokumentasikan aspek dinamis dari sistem. Diagram perilaku di UML terdiri atas: Diagram 
Use Case (Use Case Diagram), Diagram Aktivitas (Activity Diagram), Diagram Sekuen (Sequence Diagram), Diagram

\section{Implementasi}

Pada tahapan implementasi sistem terdapat beberapa hal yang perlu dilakukan, yaitu (Pressman, 2010) tahap implementasi basis data merupakan upaya untuk membangun basis data fisik hasil perancangan yang ditempatkan dalam media penyimpan (disk) dengan bantuan DBMS pada web e-commerce di toko buku Umat. DBMS yang dipilih menggunakan MariaDB. Alasan memilih MariaDB karena memiliki performa tinggi, fleksibel, gratis dan memiliki semua kemampuan MySQL.

Tahap Pengkodean merupakan tahap dimana pemrograman menulis program dengan bahasa pemrograman yang telah diplih yaitu PHP. Desain perangkat lunak web e-commerce di toko buku Umat yang telah disetujui, diubah dalam bentuk kode-kode program.

Implementasi interface atau antarmuka terdiri dari implementasi aplikasi halaman administrator (backend) dan implementasi aplikasi halaman depan (frotend).

\section{Evaluasi}

Langkah terakhir dari SDLC di mana pada tahapan ini sistem secara sistematis diperbaiki dan ditingkatkan. Hasil dari tahapan ini adalah versi baru dari perangkat lunak yang telah dibuat.

\section{Hasil dan Pembahasan}

\section{Analisis Sistem}

\section{Analisis Sistem Awal}

Sistem yang telah berjalan memiliki beberapa kelemahan. Untuk menangkap kelemahan sistem dan melakukan perbaikan dilakukan analisis dengan menggunakan metode PIECES. Berikut ini kami sajikan gambaran dan
Kelas (Class Diagram) (Whitten \& Bentley, 2007).

usulan sistem yang hendak ditawarkan secara global melalui tabel 1 .

\section{Tabel 1. Usulan sistem yang} ditawarkan secara global

\begin{tabular}{|c|c|c|}
\hline $\begin{array}{c}\text { Jenis } \\
\text { Analisis }\end{array}$ & $\begin{array}{l}\text { Kelemahan } \\
\text { Sistem Lama }\end{array}$ & $\begin{array}{c}\text { Sistem Yang } \\
\text { Diajukan }\end{array}$ \\
\hline $\begin{array}{l}\text { PERFOR } \\
\text { MANCE }\end{array}$ & $\begin{array}{c}\text { Sistem } \\
\text { pengolah data } \\
\text { produk secara } \\
\text { manual } \\
\text { menimbulkan } \\
\text { kesalahan } \\
\text { dalam } \\
\text { pemrosesan } \\
\text { data. Selain itu } \\
\text { proses } \\
\text { pencarian data } \\
\text { akan } \\
\text { memakan } \\
\text { waktu yang } \\
\text { lama. }\end{array}$ & $\begin{array}{c}\text { Sistem } \\
\text { berbasis } \\
\text { komputer } \\
\text { dapat } \\
\text { meminimalka } \\
\text { n kesalahan, } \\
\text { perhitungan } \\
\text { dihitung } \\
\text { dengan } \\
\text { perangkat } \\
\text { lunak secara } \\
\text { otomatis, dan } \\
\text { disimpan } \\
\text { dalam basis } \\
\text { data, } \\
\text { sehingga } \\
\text { dapat } \\
\text { meningkatka } \\
\text { n kecepatan } \\
\text { pemrosesan } \\
\text { data. }\end{array}$ \\
\hline $\begin{array}{c}\text { INFORMA } \\
\text { TION }\end{array}$ & $\begin{array}{c}\text { Sistem } \\
\text { pemasaran } \\
\text { memiliki } \\
\text { keterbatasan } \\
\text { konten, } \\
\text { sehingga } \\
\text { kurang } \\
\text { maksimal } \\
\text { dalam } \\
\text { menampilkan } \\
\text { detail katalog } \\
\text { produk. } \\
\text { Ketika akan } \\
\text { menampilkan } \\
\text { harga, juga } \\
\text { terbatas hanya } \\
\text { caption atau } \\
\text { badan }\end{array}$ & $\begin{array}{c}\text { Sistem } \\
\text { pemasaran } \\
\text { dengan } \\
\text { teknologi } \\
\text { web } e \text { - } \\
\text { commerce } \\
\text { semua } \\
\text { informasi } \\
\text { dapat } \\
\text { ditampilkan } \\
\text { melalui } \\
\text { website. } \\
\text { Konsumen } \\
\text { dapat melihat } \\
\text { informasi } \\
\text { produk } \\
\text { secara detail, } \\
\text { termasuk }\end{array}$ \\
\hline
\end{tabular}




\begin{tabular}{|c|c|c|}
\hline & $\begin{array}{c}\text { postingan. } \\
\text { Konsumen } \\
\text { tidak dapat } \\
\text { melihat } \\
\text { informasi } \\
\text { posisi barang } \\
\text { (tracking) } \\
\text { setelah } \\
\text { dikirim. }\end{array}$ & $\begin{array}{l}\text { ongkos kirim } \\
\text { dan posisi } \\
\text { barang } \\
\text { (tracking) } \\
\text { setelah } \\
\text { dikirim } \\
\text { hingga } \\
\text { sampai ke } \\
\text { tangan } \\
\text { konsumen. }\end{array}$ \\
\hline $\begin{array}{c}\text { ECONOM } \\
\mathrm{Y}\end{array}$ & $\begin{array}{c}\text { Dalam jangka } \\
\text { panjang biaya } \\
\text { yang biaya } \\
\text { yang } \\
\text { dibutuhkan } \\
\text { oleh pemilik } \\
\text { usaha akan } \\
\text { cukup besar } \\
\text { untuk biaya } \\
\text { promosi. }\end{array}$ & $\begin{array}{c}\text { Dalam jangka } \\
\text { pendek biaya } \\
\text { yang } \\
\text { dibutuhkan } \\
\text { akan cukup } \\
\text { besar. Tetapi } \\
\text { untuk jangka } \\
\text { panjang akan } \\
\text { menjadi lebih } \\
\text { sedikit } \\
\text { karena hanya } \\
\text { mengeluarka } \\
\text { n biaya } \\
\text { hosting dan } \\
\text { domain. }\end{array}$ \\
\hline $\begin{array}{c}\text { CONTRO } \\
\mathrm{L}\end{array}$ & $\begin{array}{c}\text { Sistem } \\
\text { pengolahan } \\
\text { data yang } \\
\text { sudah berjalan } \\
\text { akan sulit } \\
\text { melakukan } \\
\text { kontrol karena } \\
\text { pemrosesan } \\
\text { data dilakukan } \\
\text { oleh manusia } \\
\text { sehingga } \\
\text { kemungkinan } \\
\text { terjadi } \\
\text { kesalahan } \\
\text { akan besar. }\end{array}$ & $\begin{array}{c}\text { Teknologi web } \\
\text { e-commerce } \\
\text { akan } \\
\text { memudahkan } \\
\text { control } \\
\text { sehingga } \\
\text { kemungkinan } \\
\text { terjadinya } \\
\text { kesalahan } \\
\text { dapat } \\
\text { ditekan. }\end{array}$ \\
\hline $\begin{array}{c}\text { EFICIENC } \\
\mathrm{Y}\end{array}$ & $\begin{array}{c}\text { Sistem } \\
\text { pengolahan } \\
\text { data yang } \\
\text { sudah berjalan } \\
\text { kurang efisien } \\
\text { karena perlu }\end{array}$ & $\begin{array}{c}\text { Sistem } \\
\text { berbasis } \\
\text { komputer } \\
\text { lebih efisien } \\
\text { karena } \\
\text { dokumentasi }\end{array}$ \\
\hline
\end{tabular}

\begin{tabular}{|c|c|c|}
\hline & $\begin{array}{c}\text { melakukan } \\
\text { dokumentasi } \\
\text { pemesanan } \\
\text { telepon, WA } \\
\text { dan sms, } \\
\text { secara manual } \\
\text { pada kertas. }\end{array}$ & $\begin{array}{c}\text { akan } \\
\text { dilakukan } \\
\text { secara } \\
\text { otomatis. }\end{array}$ \\
\hline $\begin{array}{c}\text { SERVICE } \\
\mathrm{S}\end{array}$ & $\begin{array}{c}\text { Pelayanan pada } \\
\text { konsumen } \\
\text { akan } \\
\text { memakan } \\
\text { banyak waktu } \\
\text { karena harus } \\
\text { menunggu } \\
\text { pemrosesan } \\
\text { data. }\end{array}$ & $\begin{array}{l}\text { Konsumen } \\
\text { tidak perlu } \\
\text { datang ke } \\
\text { toko, web e- } \\
\text { commerce } \\
\text { akan } \\
\text { memudahkan } \\
\text { pemesanan. }\end{array}$ \\
\hline
\end{tabular}

\section{Analisis Kebutuhan Sistem}

\section{Kebutuhan Fungsional}

Kebutuhan fungsional adalah jenis kebutuhan yang berisi prosesproses apa saja yang nantinya dilakukan oleh sistem. Kebutuhan fungsional juga berisi informasi apa saja yang harus ada dan dihasilkan oleh sistem. Kebutuhan fungsional web e-commerce usulan dapat dilihat pada tabel 2 .

Tabel 2. Kebutuhan fungsional web $e$ commerce

\begin{tabular}{|l|l|}
\hline $\begin{array}{l}\text { No. } \\
\text { Requirement }\end{array}$ & $\begin{array}{l}\text { Nama } \\
\text { Requirement }\end{array}$ \\
\hline SPO-01 & $\begin{array}{l}\text { Sistem harus dapat } \\
\text { mengorganisasi } \\
\text { penggunanya. }\end{array}$ \\
\hline SPO-02 & $\begin{array}{l}\text { Sistem harus dapat } \\
\text { memperbaharui } \\
\text { produk. }\end{array}$ \\
\hline SPO-03 & $\begin{array}{l}\text { Sistem harus dapat } \\
\text { menampilkan } \\
\text { informasi detail } \\
\text { produk. }\end{array}$ \\
\hline SPO-04 & $\begin{array}{l}\text { Sistem harus dapat } \\
\text { digunakan untuk } \\
\text { meninggalkan } \\
\text { pesan,saran, atau }\end{array}$ \\
\hline
\end{tabular}




\begin{tabular}{|c|c|}
\hline & $\begin{array}{l}\text { kritik mengenai } \\
\text { website. }\end{array}$ \\
\hline SPO-05 & $\begin{array}{l}\text { Sistem harus dapat } \\
\text { memungkinkan } \\
\text { pengunjung dapat } \\
\text { membeli produk } \\
\text { lebih dari satu. }\end{array}$ \\
\hline SPO-06 & $\begin{array}{l}\text { Sistem harus dapat } \\
\text { memfasiltiasi } \\
\text { pengunjung } \\
\text { melakukan } \\
\text { pencarian koleksi } \\
\text { produk. }\end{array}$ \\
\hline SPO-07 & $\begin{array}{l}\text { Sistem harus dapat } \\
\text { digunakan untuk } \\
\text { melakukan request } \\
\text { buku yang tidak } \\
\text { ada di katalog. }\end{array}$ \\
\hline SPO-08 & $\begin{array}{l}\text { Sistem dapat } \\
\text { menangani diskon } \\
\text { pembelian pada } \\
\text { momen-momen } \\
\text { tertentu. }\end{array}$ \\
\hline SPO-09 & $\begin{array}{l}\text { Sistem harus dapat } \\
\text { menghitung biaya } \\
\text { ongkir. }\end{array}$ \\
\hline SPO-10 & \begin{tabular}{ll}
\multicolumn{2}{c}{ Sistem harus dapat } \\
menampilkan \\
posisi barang \\
(tracking) & setelah \\
dikirim & hingga \\
sampai ke & tangan \\
konsumen. & \\
\end{tabular} \\
\hline SPO-11 & $\begin{array}{l}\text { Sistem harus dapat } \\
\text { memberikan } \\
\text { laporan bulanan } \\
\text { dan tahunan. }\end{array}$ \\
\hline
\end{tabular}

Ada tiga user yang akan menggunakan sistem informasi ini, yaitu admin, pemilik dan pelanggan. Untuk setiap user, tanggung jawab dan hak aksesnya dapat dilihat pada tabel 3 .

Tabel 3. Pembagian user beserta tugas dan hak aksesnya

\begin{tabular}{|c|c|}
\hline $\begin{array}{l}\text { Kategori } \\
\text { Pengguna }\end{array}$ & Tugas \\
\hline Admin & $\begin{array}{l}\text { Dapat dapat } \\
\text { mengorganisasi } \\
\text { pengguna. } \\
\text { Melakukan manajemen } \\
\text { (menambah, } \\
\text { menghapus, } \\
\text { memperbaharui, } \\
\text { mencari) produk. } \\
\text { Memperbaharui diskon. } \\
\text { Memperbaharui stok } \\
\text { produk } \\
\text { Melihat request produk. } \\
\text { Mengorganisasi pesan } \\
\text { yang masuk }\end{array}$ \\
\hline $\begin{array}{l}\text { Pemilik } \\
\text { (Owner) }\end{array}$ & $\begin{array}{l}\text { Melihat stok produk. } \\
\text { Menetapkan diskon. } \\
\text { Melihat request produk. } \\
\text { Melihat laporan } \\
\text { bulanan dan tahunan. }\end{array}$ \\
\hline Pelanggan & $\begin{array}{l}\text { Memperbaharui } \\
\text { profilnya. } \\
\text { Melihat informasi } \\
\text { produk. } \\
\text { Melakukan pencarian } \\
\text { produk dan request } \\
\text { produk. } \\
\text { Dapat membeli produk } \\
\text { lebih dari satu. } \\
\text { Melihat posisi barang } \\
\text { (tracking) } \\
\text { dikirim hingga sampai } \\
\text { ke alamat. } \\
\text { Meninggalkan pesan, } \\
\text { saran, atau kritik } \\
\text { mengenai website. }\end{array}$ \\
\hline
\end{tabular}

\section{Kebutuhan Non Fungsional}

Kebutuhan non fungsional web web e-commerce berisi tentang properti perilaku yang dimiliki oleh sistem meliputi hardware, software dan server webhosting. Berikut ini adalah penjabaran tentang spesifikasi hardware, 
software dan server webhosting yang dibutuhkan.

Processor Celeron Dual Core $2.16 \mathrm{GHz}$, RAM 512 MB, Harddisk $80 \mathrm{~GB}$, dan LCD beresolusi $1024 \times 768$ pixels, Mouse, Keyboard

Kebutuhan software dengan spesifikasi minimal perangkat lunak yang dibutuhkan untuk pengoperasian sistem yaitu Microsoft Windows 7 dan Linux Ubuntu 12.0, dan Browser seperti Google Chrome, Mozilla Firefox

Kebutuhan webhosting untuk meletakan perangkat lunak agar dapat diakses dengan baik yaitu

Memory $1 \mathrm{~Gb}$, Processor single core xeon $2.6 \mathrm{GHz}$, Hardisk SSD 30G dan Transfer Rate 3 TB per bulan.

Desain Sistem

Pada tahapan desain ada beberapa dokumen yang akan dibuat, meliputi Diagram Use Case (Use Case Diagram), Diagram Aktivitas (Activity Diagram), Diagram Sekuen (Sequence Diagram), Diagram Kelas (Class Diagram), dan desain antarmuka.

Diagram Use Case (Use Case Diagram)

Dalam perancangan pemrograman berorientasi objek diperlukan skenario untuk memodelkan aspek perilaku sistem, berikut ditampilkan use case diagram pada sistem yang dibuat :
Hardware minimum untuk pembuatan perangkat lunak adalah dengan spesifikasi sebagai yaitu

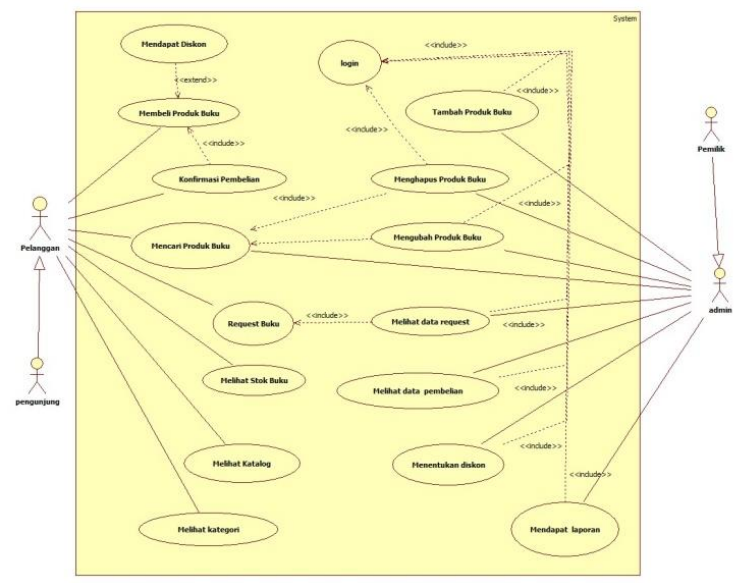

Gambar 2. Diagram use case (use case diagram) pada took buku Umat

Pada gambar 2 terdapat 3 aktor yaitu pelanggan, admin dan pemilik. Admin dapat memperbaharui produk dan menginputkan diskon pada halaman administrator. Pelanggan dapat memilih tiap kategori buku yang ingin dilihat, misal kategori buku biografi, maka akan tampil seluruh buku yang berkaitan dengan biografi dan dapat memilih untuk melihat setiap detail produk bukunya. Selajutnya jika buku yang didapat sudah sesuai, pelanggan dapat membeli produk buku di katalog sistem Informasi yang ditampilkan meliputi konfirmasi pembelian dan mendapatkan diskon tiap pembeliannya. Pelanggan dapat melihat stok buku, jika stok buku habis maka pelanggan tidak dapat melakukan pembelian. Pelanggan dapat melakukan request buku ketika pencarian buku yang diinginkan tidak ada. Admin juga dapat melihat data request buku yang diminta pelanggan. Admin dapat mencari data pelanggan yang melakukan pembelian.

\section{Diagram Aktivitas (Activity Diagram)}

Untuk menggambarkan logika sebuah proses alur kerja sistem. Dalam beberapa hal seperti bagaimana objek- 
objek bekerja, untuk perlu dibuatkan Diagram Aktivitas baik pelanggan terhadap sistem, maupun admin terhadap

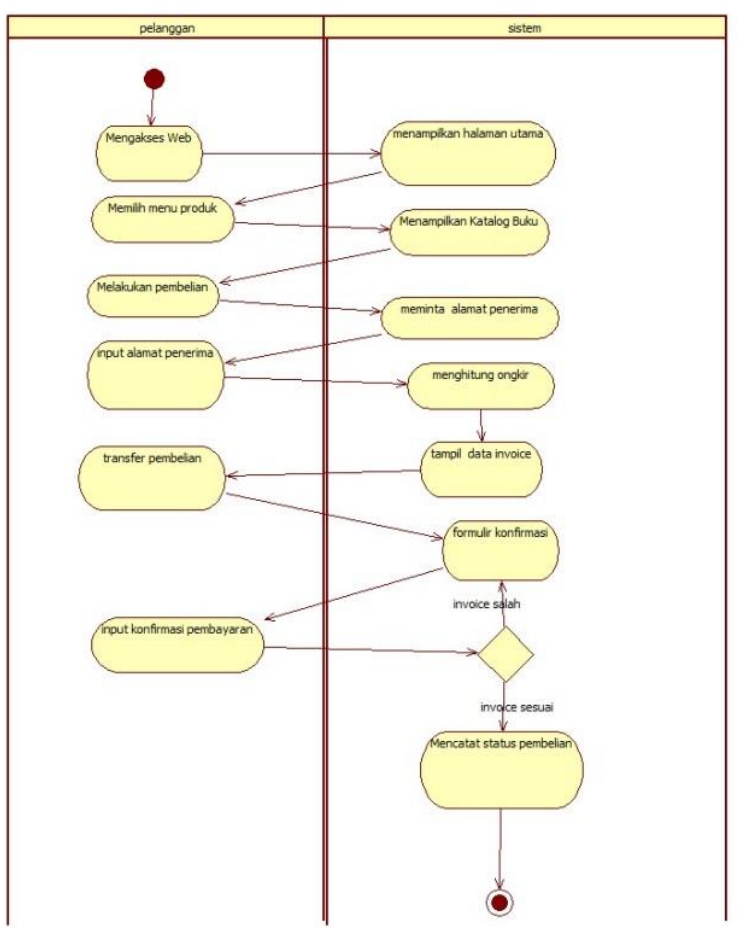

\section{Gambar 3. Diagram aktivitas proses pembelian pada took buku Umat}

\section{Diagram Kelas (Class Diagram)}

Class diagram mendeskripsikan jenis-jenis objek dalam sistem dan berbagai macam hubungan statis yang terdapat diantara objek, operasi sebuah objek dan batasan yang terdapat dalam hubungan-hubungan objek tersebut. Struktur data yang tetap di database dimodelkan sebagai class entity dan sebagai relasi diantara class entity. Class entity ini perlu dipetakankan ke struktur data yang dikenal oleh database. Sehingga pembuatan class diagram ini akan membantu dalam pembuatan database. Gambar 4 menunjukan Class diagram pada toko buku Umat. sistem, berikut ini adalah activity diagram pelanggan terhadap sistem :

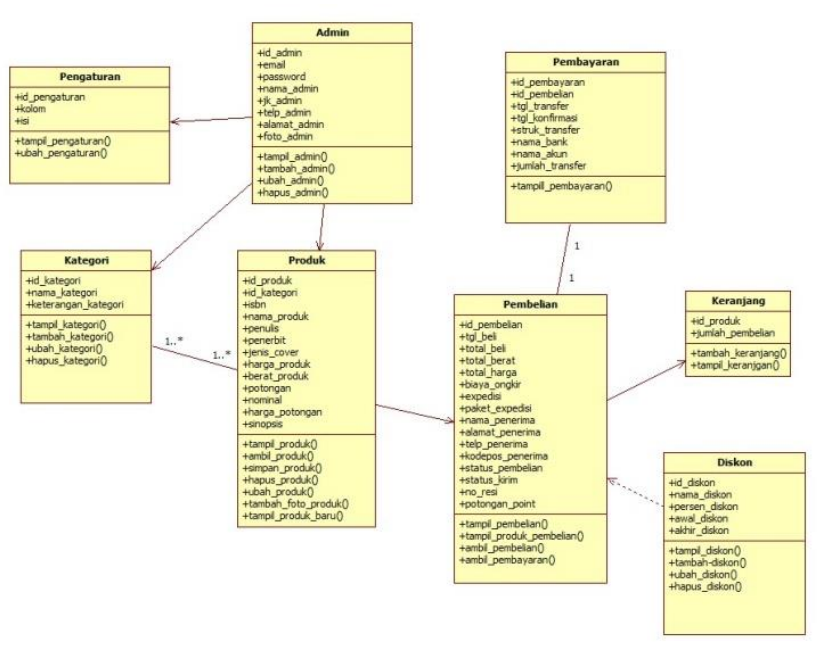

Gambar 4. Diagram kelas (Class

Diagram) pada took buku Umat

\section{Diagram Sekuen (Sequence Diagram)}

Sequence

diagram

menggambarkan kelakuan objek pada usecase dengan mendeskripsikan waktu hidup objek dan pesan yang dikirimkan dan diterima antar objek. Dalam menggambarkan diagram ini, harus diketahui objek-objek yang terlibat dalam sebuah usecase beserta metodemetode yang dimiliki kelas. Gambar 5 menunjukan sequence diagram pada toko buku Umat.

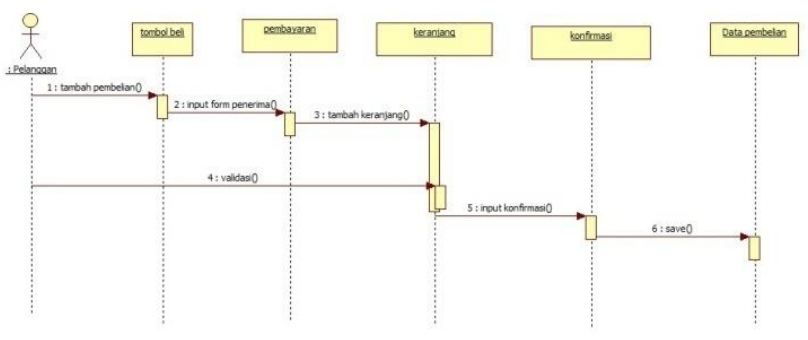

\section{Gambar 5. Diagram sekuen proses pembelian pada took buku Umat}

\section{Desain Antarmuka Perangkat Lunak}

Desain interface atau antarmuka terdiri dari desain halaman administrator (backend) dan desain aplikasi halaman 
depan (frotend). Gambar 6 menunjukkan menu halaman administrator (backend).

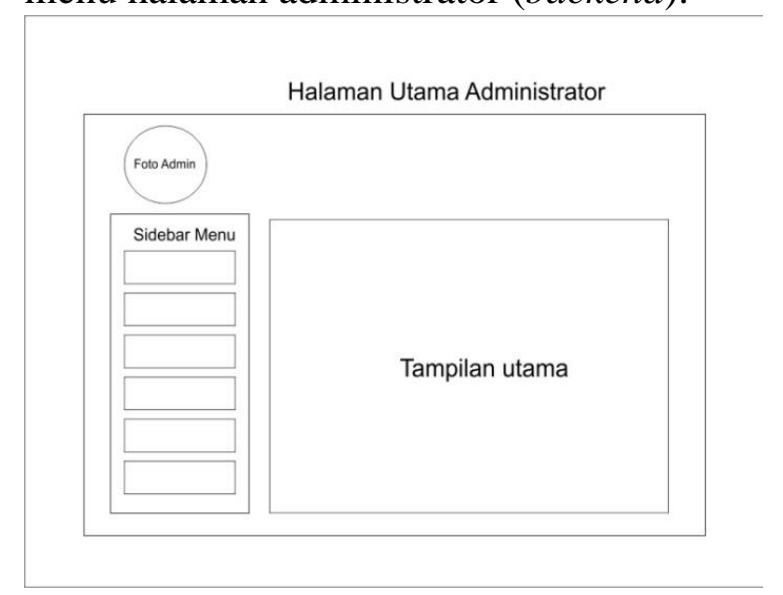

\section{Gambar 6. Rancangan menu halaman admin (backend)}

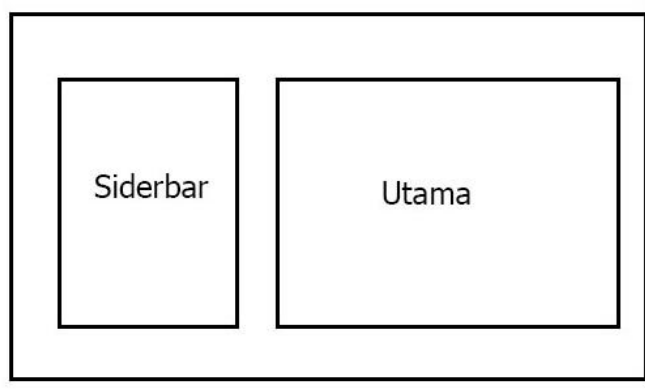

\section{Gambar 7. Rancangan menu halaman depan (frontend)}

\section{Implementasi Basis Data}

Tahap selanjutnya adalah membangun basis data fisik hasil perancangan, yang ditempatkan dalam media penyimpan dengan bantuan DBMS MariaDB. Gambar 9 memperlihatkan transformasi dari model data yang telah selesai dibuat struktur basis data sesuai DBMS yang dipilih pada table-tabel web e-commerce dalam DBMS MariaDB.

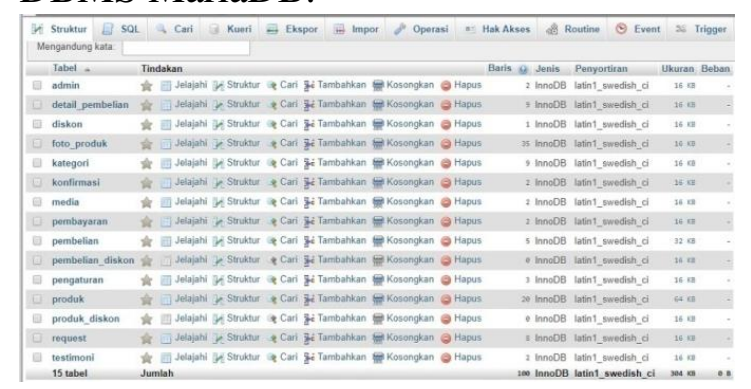

\section{Gambar 8. Implementasi tabel web $e$ -} commerce

\section{Pengkodean}

Desain perangkat lunak web $e$ commerce toko buku Umat yang telah disetujui, diubah dalam bentuk kodekode program bahasa pemograman PHP. Contoh pengkodean dalam web $e$ commerce toko buku Umat dapat dilihat pada gambar 9 .

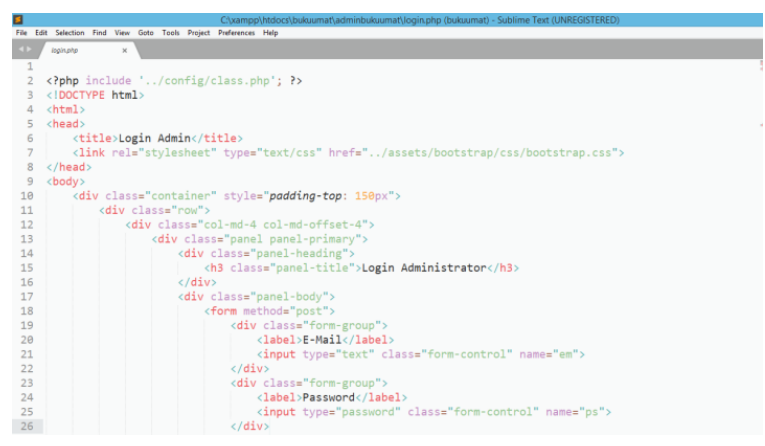

Gambar 9. Pengkodean web $e$ -
commerce toko buku Umat

\section{Implementasi interface}

Implementasi interface atau antarmuka terdiri dari antarmuka halaman depan (frontend) dan antarmuka halaman administrator (backend). Implementasi antarmuka halaman depan diperlihatkan pada gambar 10 dan halaman administrator (backend) diperlihatkan pada gambar 11.

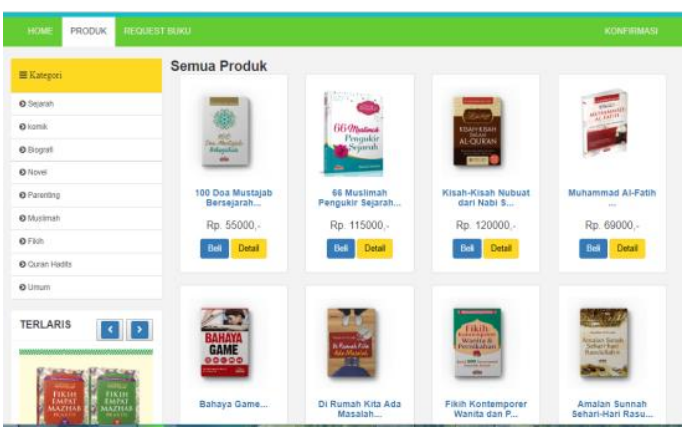


Gambar 10. Implementasi halaman depan (frontend) web e-commerce toko buku Umat

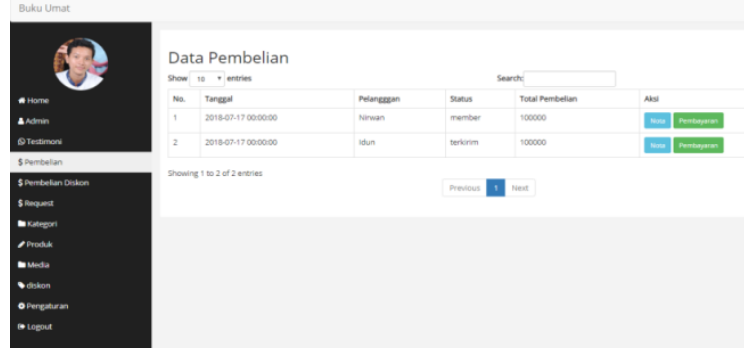

Gambar 11. Implementasi halaman administrator (backend) web e-commerce toko buku Umat

\section{Evaluasi}

Sistem telah dibuat perlu dilakukan evaluasi dan pengujian untuk mengetahui apakah bisa berjalan dengan baik. Pengujian sistem dilakukan dengan menggunakan data valid dan data yang tidak valid menurut alur logika tertentu. Untuk data valid memiliki aturan jika berhasil dieksekusi oleh sistem maka akan memberikan nilai TRUE, jika tidak dieksekusi akan memberikan nilai FALSE. Untuk data tidak valid, jika data berhasil di eksekusi oleh sistem akan memberikan nilai $F A L S E$, tetapi jika tidak dieksekusi akan memberikan nilai TRUE.

Tabel 4. Hasil pengujian untuk menu data produk

\begin{tabular}{|l|l|l|l|l|l|}
\hline NF & DV & DTV & HDV & HDTV & S \\
\hline Id_produk & 1 & Kosong atau & TRUE & FALSE & OK \\
\hline isbn & $\begin{array}{l}979-3485- \\
53-7\end{array}$ & $\begin{array}{l}\text { Kosong } \\
979-34 \mathrm{xx}-53-\mathrm{y}\end{array}$ & TRUE & FALSE & OK \\
\hline nama_produk & $\begin{array}{l}100 \quad \text { Doa } \\
\text { Mustajab }\end{array}$ & Kosong & TRUE & FALSE & OK \\
\hline penulis & $\begin{array}{l}\text { Muhamad } \\
\text { Ali Usman }\end{array}$ & $\begin{array}{l}\text { Muhamad Al1 } \\
\text { Usm4n }\end{array}$ & TRUE & FALSE & OK \\
\hline penerbit & Aqwam & Kosong & TRUE & FALSE & OK \\
\hline harga & 5000 & $500 \mathrm{x}$ & $T R U E$ & $F A L S E$ & OK \\
\hline berat & 1000 & $100 \mathrm{y}$ & $T R U E$ & $F A L S E$ & OK \\
\hline
\end{tabular}

Keterangan $:$ NF = Nama Field; DV = Data Valid; DTV = Data Tidak Valid; HDV $=$ Hasil Data Valid ; HDTV = Hasil Data Tidak Valid; $S=$ Status

\section{KESIMPULAN DAN}

\section{SARAN}

\section{Kesimpulan}

Dalam hasil penelitian ini, dapat disimpulkan sebagai berikut Web ecommerce di toko buku Umat mampu menampilkan informasi produk secara detail, menghitung ongkos kirim beberapa ekspedisi di Indonesia secara otomatis dan menampilkan posisi barang (tracking) setelah dikirim hingga sampai ke tangan konsumen. Web e-commerce di toko buku Umat dapat mempermudah promosi produk dan memperluas pemasaran sehingga semua orang dimanapun berada dapat berbelanja secara online. 


\section{Saran}

Berdasarkan kesimpulan di atas dan hasil pengamatan di lapangan maka perlu dikemukakan beberapa saran untuk pengembangan rancangan sistem lebih lanjut yaitu validasi sistem informasi untuk selanjutnya dapat dilakukan penambahan metode pengujian dan perangkat lunak dikembangkan dengan 2 model DBMS, yaitu model relasional dan non-relasional. Basis data non-

\section{Daftar Pustaka}

Alghamdi, S., \& Bach, C. (2014). Technological Factors to Improve Performance of Marketing Strategy. ASEE 2014 Zone I Conference University of Bridgeport.

Balaji, S., \& Murugaiyan, M. S. (2012). Wateerfall Vs V-model Vs Agile: A Comparative Study On SDLC. International Journal of Information Technology and Business Management, 2(1), 26-30.

Fithri, D. L., Utomo, A. P., \& Nugraha,

F. (2017). Pemanfaatan ECommerce Populer Untuk Optimalisasi Pemasaran Produk Pada Kub Bordir Kurnia Kudus. Jurnal SIMETRIS, 8(2), 819-824.

Khan, A. G. (2016). Electronic Commerce: A Study on Benefits and Challenges in an Emerging Economy. Global Journal of Management and Business Research: Economics and Commerce, 16(1), 18-22. Retrieved from

https://globaljournals.org/GJMBR_ Volume16/3-Electronic-CommerceA-Study.pdf

Mumtahana, H. A., Nita, S., \& Tito, A. W. (2017). Pemanfaatan Web ECommerce untuk Meningkatkan relasional diterapkan untuk prosesproses yang membutuhkan kecepatan, jumlah data besar dan non transaksional, sehingga keterbatasan basisdata relasional dapat tertutup dengan kelebihan basis data non-relasional.

Strategi Pemasaran. KHAZANAH INFORMATIKA, 3(1), 6-15.

Pressman, R. S. (2010). Software Engineering: A Practitioner's Approach (7th ed.). New York: McGraw-Hill.

Saptari, A., \& Saptari, M. A. (2017). Analisa Dalam Mengukur Kualitas Pelayanan Terhadap Kepuasan Konsumen Menggunakan Metode PIECES. Jurnal Visioner \& Strategis, 6(September), 39-47.

Shahriari, S., Shahriari, M., \& Gheiji, S. (2015). E-Commerce and It Impacts On Global Trend and Market. International Journal of Research GRANTHAALAYAH, 3(4), 49-55.

Susandi, D., \& Sukisno. (2017). Sistem

Penjualan Berbasis E-Commerce Menggunakan Metode Objek Oriented pada Distro Dlapak Street Wear. Jurnal Sistem Informasi, 4(1), 5-8.

Whitten, J. L., \& Bentley, L. D. (2007). System Analysis and Design Methods 7th. (McGrawHill, Ed.) (7th ed.). New York: McGrawHill. 